\section{Original} Article

Access this article online

Website:

www.ajobe.org

DOI:

10.4103/1817-7417.123079

Quick Response Code:

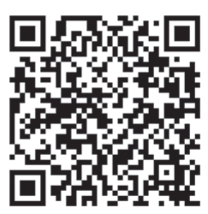

Address for correspondence: Domènec Melé,

IESE - Business School, University of Navarra, Av. Pearson 21, 08043 Barcelona, Spain.

E-mail: mele@iese.edu

\title{
Antecedents and current situation of humanistic
}

management

\section{Domènec Melé}

Department of Business Ethics, IESE Business School, University of Navarra, Spain, IESE - Business School, University of Navarra, 08043 Barcelona, Spain

\section{ABSTRACT}

Humanistic management is generally presented as an alternative perspective to the economic paradigm in management and organisational theories. We find both humanism and economicism in the first stages of modern management, and they still persist at the beginning of the $21^{\text {st }}$ century. This paper reviews the antecedents and current situation of humanistic management. Although economicism is still dominant, it has received severe criticism and several management approaches discussed here can contribute to further development of humanistic management. These include person-organisation fit, peoples' involvement in organisations, the consideration of business as a human community, comprehensive approaches to decision-making, stakeholder management, values-based management, as well as ethics and corporate responsibility in management, personal competencies and positive organisational scholarship.

Key words: Business ethics, economic paradigm, history of management, humanism, humanistic management, management development

\section{INTRODUCTION}

In the $20^{\text {th }}$ century, the term humanistic management appeared in business and managerial literature only occasionally and generally with a narrow meaning. According to Swart (1973) this term is synonymous with job enrichment, a proposal first made by Herzberg (1968), which involves motivating employees by giving them more responsibilities and variety in their jobs, in order to increase their satisfaction and productivity. Similarly, Daley affirmed that "humanistic management is quintessentially behaviouralistic and focused primarily on human motivation" (1986:131). Lilienthal (1967:1968) adopted a different perspective by arguing that management requires a humanistic outlook on life, rather than merely mastery of technique, thereby presenting management as a humanistic art. Cunningham and Tichy (1983) advocated reforms within the corporate community, including changes in relationships, attitudes and business methods that influence and shape the lives of human beings throughout the corporate culture. Aktour (1992) went further by affirming that Western organisations need to rely more on a radical-humanistic conceptualisation than on the functionalistic tradition and suggested neo-Marxist humanism. French and Bell (1999) pointed out the need to introduce humanistic values in organisational development. He emphasised the importance of individuals, respect for freedom and avoiding the misuse of power. In his view, people are basically good.

At the turn of the $21^{\text {st }}$ century, a renewed interest in humanistic management appeared. Melé (2003) presented humanistic management as a challenge. Drawing from historical sources, he understood humanistic management as "a management that emphasises the human condition and is oriented to the development of human virtue, in all its forms, to its fullest extent" (2003:79). Some years later, the Humanistic Management Network was created "to encourage business to embrace a more 'life-serving' approach by integrating humanistic values intro their core strategy" (Spitzeck et al., 2009:xxix). This network has promoted a number of publications on humanistic management (Amann et al., 2011; Kimakowitz et al., 2011; Spitzeck, 2009). Other articles (Acevedo, 2012; Beaudreau, 2012; Melé, 2012a; Spitzeck, 2011) and collective works (special issue of the Journal of Business Ethics, Vol. 88, Issue 3; Melé and Dierksmeier, 2012; Rosanas and Ricart, 
2012) are also evidence of the increasing interest in the concept. Other scholars (Alexander and Buckingham, 2011; Lutz, 2009; Maak and Pless, 2009; Mbigi and Maree, 2005; Moore, 2005; Rosanas, 2008; and Sisón et al., 2012, among others), even without explicitly mentioning humanistic management, present managerial perspectives that can also be considered humanistic.

The aim of this paper is to contribute to an understanding of humanistic management by discussing its early antecedents and above all, the current developments in management that contribute to it. It is structured as follows: First, we introduce the theme by contrasting humanism and economicism. Second, we review early antecedents of humanistic management through several influential pioneers of management thought. Then we analyse some current proposals related to humanistic management. We conclude by presenting some reflections on the further development of humanistic management.

\section{HUMANISM VERSUS ECONOMICISM}

\section{Humanism}

Although there are several ways of understanding humanism, this paper draws from the French philosopher Jacques Maritain, who wrote that humanism "tends essentially to render man more truly human and to manifest his original greatness by having him participate in all that can enrich him in nature and history...[I]t at once demands that man develop the virtualities contained within him, his creative forces and the life of reason, and work to make the forces of the physical world instruments of his freedom" (1996, Vol. II, p. 153). These words contain suggestive ideas that lead us to consider how business and management should practise humanism. Business should respect the humanity of people, treating them always as an end and never as a mere means; people should participate in business in a way appropriate to each situation, seeking to avoid others feeling themselves as simple receptors of orders; business should favour human potential in aspects such as creativity, rationality and character and foster the growth of individuals as human beings; last, but not least, companies should create a culture where people can exercise freedom, with a sense of responsibility and an awareness of making a real contribution to human well-being.

In Catholic social teaching, we find a statement that perhaps summarises what humanistic management is about: "Man is the source, the centre and the purpose of all economic and social life" (Vatican Council II, Gaudium et spes, n. 63). In practice, however, this centrality of the human being is not always the case. Actually, one can observe two mainstream tendencies in business, one humanistic, in which persons come first, and another, which can be termed economistic. In the latter, priority is given to economic results, subordinating human dignity, rights, and growth to this end. Whereas in the humanistic approach persons are central, in the economistic approach, people become a mere part of the production or distribution processes, without full respect for their rationality, freedom, and capacity to grow as human beings.

\section{Economicism}

Although economicism can have different meanings, it is generally understood to denote the prevalence of the economic view over any other. For years, economicism in the business context has been represented by the expression 'business is business,' meaning that business takes precedence over any ethical or humanistic considerations. Thus, the implication is that profits - or maximising shareholder value - are the supreme end of the company and any other consideration, including humanism, has to be subordinated to this goal. This is the well-known position of Friedman $(1962 ; 1970)$ and Jensen (2001), although the latter manifests in a more nuanced fashion (he accepts concern for stakeholder interests if and only if, this contributes to the bottom line). According to Ghoshal, a recognised management scholar who died in 2005, "Friedman's version of liberalism has indeed been colonising all the management-related disciplines over the last half century" (2005: 84). Now-a-days, although some humanistic approaches can be found, as we will explain below, the economistic mentality has not been completely overcome and its influence can be noted in many places and situations.

The antecedents of both humanistic management and management based on economicism can be traced back to the pioneers of management thought. Humanistic management is clear in the works of three well-known authors: Taylor, Ford, and Fayol.

Before Taylor wrote his influential book, scientific management, in 1911, the organisation of factories and workshops was left in the hands of workers, to their experience and intuition. Productivity was very low indeed. Taylor's proposal was to substitute the experience and intuition of workers for an accurate analysis of manual activities and the subsequent planning of every operation with economy of movement. The main role of management was to prepare the workers' activity, including a detailed description of every task. In this way, management was understood as a technical task, while workers were mere executors who were not required to think.

The positive side of this rationalisation of work was that it brought about a substantial increase in productivity and consequently, an appreciable rise in both profits and wages. Yield became even higher when the assembly line was later implemented by Henry Ford and his engineers in his car manufacturing factories. It was thought that everyone would be happy to apply these production methods with 
such economic rewards. However, rationalisation of work also had a dark side. Very soon, complaints against this style of management started to emerge. Workers and unions claimed that this kind of organisation led to a monotonous repetition of tasks, the whole day, every week, which caused boredom, stress, dissatisfaction, lack of workplace morale, absenteeism, and in some cases, a greater risk of what are now called repetitive strain injuries. Beyond these problems, one discovers a considerable problem in humanistic management: Scientific management. While it increases productivity, it leads to an understanding of management as simply a technique, lacking in any human consideration further than the human capability to repeatedly perform certain mechanical activities.

In 1922, Henry Ford tried to justify his approach by not only increasing productivity, but also citing 'human reasons'. In his own words: "The average worker wants a job in which he does not have to put much physical effort. Above all, he wants a job in which he does not have to think" (quoted by Swart, 1973:41). Maybe some workers prefer this type of job to one that requires more physical and mental effort. It is even possible that some workers prefer routine jobs because these fit well with their capabilities and degree of education. However, it is doubtful that this approach is the most appropriate for every worker. Ford showed his genius in many innovative developments in the car industry, but it is probably safe to say that he will not be remembered for his humanistic vision of business. Taylor and Ford understood management as a mere technical function and its execution as giving order to and controlling worker performance. Their visions tend to reduce human beings to a sort of mechanism in production. Individual personality, personal talents, human relations, personal motivations (except the economic ones), satisfaction and personal growth are completely forgotten.

\section{THE RISE AND EVOLUTION OF HUMANISTIC MANAGEMENT}

In the second and third decades of the $20^{\text {th }}$ century, various authors presented a more humanistic view of management. They could be considered the first antecedents of humanistic management. One was Follett, who is considered a prophet of modern management (Graham, 1995). Follett had a view of management that differed substantially from Taylor's and from that of most of her contemporaries. In contrast to Taylor, Follett $(1940 ; 1987)$ had no interest in the amount of energy spent, or in the breaks that should be taken by the workers to avoid fatigue. Her interest was in how to get people to cooperate.

Similarly, Chester I. Barnard, another pioneer in management thought, also insisted on the importance of cooperation. The centrality of persons in business and above all, the necessity of knowing the human being were especially apparent. He wrote:
I have found it impossible to go far in the study of organizations or of behaviour of people in relation to them without being confronted with a few questions which can be simply stated. For example: What is an individual?' 'What is a person?' 'To what extent do people have power of choice or free will?' (1938:8; 1968).

William Wolf, who studied Barnard in some depth, stressed that "Central to understanding Barnard's life and thoughts is his humanistic position. He attached primary importance to man and to the development of man's faculties, affairs, and well-being" (1974:46).

Soon, Elton, Mayo $(1933 ; 1946)$ stressed the importance of human behaviour in organisations, and Maslow (1954) proposed the importance of human needs and motivations in behaviour, which can be considered a humanistic approach to a degree, although one which is limited. Mayo's line was followed with significant contributions by McGregor (1960), Herzberg (1959; 1968; 1976) and Argyris (1957), among others. In one way or another, they stressed the importance of developing a meaningful job, decentralising power in organisations and providing workers with opportunities for decision-making. They held that this humanistic approach would lead to more efficient organisations. It could be questioned whether these approaches were actually humanism or rather a masked form of economicism. The answer may well be affirmative, but we must not forget that business needs to make profits; however, dealing with people in a more humane way can contribute, in certain circumstances, to increased performance.

Another important antecedent of humanistic management is Peter Drucker, probably the greatest management guru of all time. Drucker's management philosophy is based on a communitarian vision (Kurzynski, 2009; Schwartz, 2004). He regarded the business corporation as a human community and a social organisation, a micro-society within the larger society, in addition to being an economic entity. He harmonised making profits and the social contribution of business and gave the individual a notable importance within the organisation. According to Drucker, "organization is the means through which man, as an individual and as a member of the community, finds both contribution and achievement" (1973:810).

In the1960's and in the years that followed, business schools and scholarship became increasingly centred on management based on social sciences and to a great extent, the same focus is still found now-a-days in many business schools. This was a consequence of the Gordon and Howell reports (1959), sponsored by the Ford/Carnegie Foundation, which proposed a business school model based on social science and academic rigour as an alternative to the previous model based on learning from practical experience and 
elemental, but useful schemes. The underlying philosophy of management approaches developed then and quite popular at that time, was logical positivism. This advocates a complete separation between facts and values and focuses on objective facts and the development of analytical models applied with scientific rigour. Human and ethical aspects were banished to the subjective realm and excluded from analytical models. Humanism was substituted with studies on human behaviour and how to manage it to improve performance.

However, at least from the early 1980s, the strong emphasis on social science and scientific rigour began to produce concern among practitioners and some academics, due to its lack of relevance for management. This concern manifested in a number of successful and readable books on cases and business stories, in which people and their humanity and culture played an important role. This was the case, for instance, in a variety of works: In search of excellence: Lessons from America's best run companies by Peters and Waterman (1982), Built to last: Successful habits of visionary companies by Collins and Porras (1994) and Good to great: Why some companies make the leap, and others don't by Collins (2001).

In the late $20^{\text {th }}$ century and early $21^{\text {st }}$ century, economics became the dominant model in most business schools in the United States and other countries, mainly through the Transactional Cost Theory and the Agency Theory, in which the whole business is seen exclusively in economic terms, and there is no room for ethics, or ethics is reduced to a tool for profit-making. In both theories, rooted in neo-classic economics, the model of man is a neo-classical homo economicus, with some modifications of the rational and self-maximising individual presented in the classical homo economicus, but still far from being a model that includes other relevant aspects of the richness of the human being.

At the turn of the millennium, mainstream management and organisation theories were severally criticised (e.g. Adler, 2004; Bennis and Toole, 2005; Mitroff, 2004; Mintzberg, 2004). Ghoshal (2005) emphasised the individualistic and negative vision of the human being underlying such theories. He wrote:

Currently influential theories of business and management span diverse academic disciplines including psychology, sociology, and of course - preeminent of all - economics. Collectively, however, they have increasingly converged on a pessimistic view of human nature, on the role of companies in society, society, and of the processes of corporate adaptation and change (2005:82).

This claim, which suggests a broader and more realistic view of the human being and abandons the purely scientific and technical view of management, has been reinforced by the global economic crisis of 2008 and the following years. Locke and Spender, two retired professors of management, wrote a book (2011) that adopts a view more critical still than Ghoshal's. They blame management education and the training industry for perpetuating the 'neo-classical economic mystique,' which, in their view, has had a disastrous effect on business leadership.

On the positive side, there is increasing concern for a more humanistic management style, as noted in the introduction, and for a new view of management. In their Manifesto for management, Ghoshal et al. (1999) proposed replacing the pessimistic assumptions underlying the nature of current management with a more realistic set that calls on managers to act out a positive role. In a more recent Manifesto for $a$ better management, Andreu and Rosanas (2012) suggested a comprehensive view of management, in which people are primordial. On his part and facing the abovementioned economic crisis, Pope Benedict XVI made a challenging call: The different aspects of the crisis, its solutions and any new development that the future may bring, are increasingly interconnected, they imply one another, they require new efforts of holistic understanding and a new humanistic synthesis (2009:n. 21).

Although the fruits of these labours need time to ripen, some contributions to humanistic management in the last three decades can now be enjoyed. This is the topic of the next section.

\section{CURRENT DEVELOPMENTS CONTRIBUTING TO HUMANISTIC MANAGEMENT}

In the present business situation, one can appreciate light and shade in the consideration of persons within organisations. On one hand, the economistic view persists in a great variety of aspects in business life, but, on the other, approaches and developments of humanistic content, often with old roots, are also emerging in business and management.

\section{Person-organisation fit}

The first current development contributing to humanistic management is the emphasis on person-organisation fit, which can be traced back to the approach of Taylorism and Fordism and their narrow view in understanding such a fit. In order to solve the problems of work monotony, introducing innovations in job design was proposed. Among these were job rotation, which is a systematic shifting of employees from one job to another; job enlargement, in which the assignments to each worker are expanded to include additional or similar tasks; and job enrichment, in which there is variety in tasks assigned to employees and some responsibility for, and control over their jobs. Through job redesign, which can be included under job enrichment, work is restructured in ways that the employee's skills, character and attitudes fit the needs of the organisation. Cultivating a worker-job match can include combining tasks, forming work groups and establishing closer 
customer association. However, the concept of job enrichment opened the door to a wider consideration of persons and also to a better understanding of the richness and complexity of human nature.

Today, the trend is to pay attention to person-organisation fit, which refers to a match in needs, desires, or preferences between employee and employer (organisation) (Kristof, 1996). The real problem for many companies is to attract talented employees. In this regard, it is argued that potential employees are going to be more attracted to companies if the individuals believe that their own personal characteristics are aligned with the organisation's attributes (Cable and Judge, 1994; Chatman, 1989; Judge and Bretz, 1992).

Both job redesign and concern for person-organisation fit, or person-environment fit - another related concept - underline respect for the individual, and the idea that every person is different and should be treated in accordance with his or her qualities and personality.

\section{Peoples' involvement in organisations}

A second contribution to humanistic management is that of giving increased importance to peoples' involvement in organisations. In the Taylorist approach, management is based on giving orders. Managers have a real power over workers, whereas the latter became mere executors of managerial orders. Facing this position, Follett - mentioned above - reacted, claiming that it was right for workers to resist management having power over them and also for employers to resist union efforts to invert the situation and gain power over them. She proposed changing power over for power with. The distinction was humanistic, as Follett herself explained with an example: "You have rights over a slave; you have rights with a servant" (Follett, 1940:101). In addition, she suggested that power over is not effective, because people resist; they do not want to be led or patronised (Follett, 1940:103).

Since then, many other authors have insisted on participative management and putting people first, where people are increasingly involved in their organisations' decision-making. Pfeffer and Veiga pointed out at the turn of the $21^{\text {st }}$ century:

Over the past decade or so, numerous studies conducted both within specific industries and samples of organisations that cross industries have demonstrated the enormous economic returns obtained through the implementation of what are variously called high involvement, high performance, or high commitment management practices (1999:37).

However, these scholars immediately added something paradoxical: "Trends in actual management practice are, in many instances, moving in a direction exactly opposite to what this growing body of evidence prescribes" (1999:37). Some recent events are in the mind of everybody: brutal downsizing and delocalisation of plants with scarce consideration for the laid-off employees and so on. Fortunately, this is not the case for many firms that not only consider people, but also try to involve them in managing the business and try to foster the development of their creativity and willingness.

\section{Business as a human community}

A third important humanistic contribution is the consideration of business as a community of persons, in contrast to the vision that organisations are only dehumanised mechanisms without any goal other than to enrich their owners. Companies are considered a set of contracts, and nothing else. This is a premise assumed by some popular economic theories, such as Agency Theory (Jensen and Meckling, 1976) and Transaction Cost Theory (Williamson, 1975). In this economistic vision, people are presented as subjects with interests and preferences, who are contracted.

Ordinary language also refers to the company as an object owned by shareholders. In mergers and acquisitions, companies are said to have been bought or sold. However companies are not objects like a piece of land or a car. Companies are not only an account of capital, but, above all, they are human realities. Handy (1999) criticised the current language of business on this point: "The language of property and ownership no longer works as well as it should in modern society." The explanation is that "the idea of a corporation as the property of the current holders of its shares is confusing because it does not make clear where power lies." However the inappropriateness of talking in these terms is not only because some facts have changed. There is an ethical consideration:

It is an affront to natural justice in that it gives inadequate recognition to the people who work in the corporation and who are, increasingly, its principal assets. It might even be considered immoral for people to talk of owning other people, as shareholders implicitly do (1999:50).

The humanistic view is that companies are much more than mechanisms for profits and a mere set of contracts. Because humans have capacity for friendly and cooperative relationships, they have many links other than the merely contractual. As Solomon wrote, an organisation is defined by "relationships between people, whether of affection, friendship, loyalty, power, position or expertise." The author added that

Social contract theory only muddles this picture because it suggests, almost always falsely, that the primary relationships involved are predominantly contractual. This is a sure way to misunderstanding that corporations are communities (1994:274).

Individuals, with their personalities, interests, and personal goals, do not disappear within a corporation. However, business is not only a collection of self-interested individuals: To see business as a social activity is to see it as a practice 
that both thrives on competition and presupposes a coherent community of mutually concerned as well as self-interested citizens (Solomon, 1992:146).

Understanding business as a community of persons explains organisational phenomena such as shared knowledge. The structure and quality of relationships with the firm is likely to be highly influential in creating and exchanging knowledge (Hansen, 1999; Uzzi, 1996). Through membership in a social community, including a business firm, identification with a community is developed; this identification process changes the character and quality of the behaviour of its members (Kogut and Zander, 1995). Another perspective that leads to understanding organisations as communities comes from Social Capital Theory, which assumes the existence of communities. Social Capital Theory provides a sound basis to explain why organisations gain advantage by creating intellectual capital and that this could be a firm's most enduring source of competitive advantage (Nahapiet andGhoshal, 1998; Cohen and Prusak, 2001; Moran, 2005).

This approach is a great contribution to humanistic management, inasmuch as business as a community of persons could be considered a pillar of humanistic management (Melé, 2012a).

\section{Decision-making: A comprehensive approach}

A comprehensive approach to business and humanistic aspects was developed by Juan A. Pérez-López (1991; 1993, see also Argandoña, 2008; Rosanas, 2006), which is rooted in Aristotelian tradition. This approach, although still incomplete (Pérez-López died in 1996), could be considered the fourth contribution to humanistic management. It sees the human being as a whole and considers key human aspects, such as freedom, rationality (not reduced to the instrumental), learning and the role of virtues. He focused on decision-making in organisations as a crucial aspect of management. His starting point is a theory of motivations, which considers not only extrinsic motives for acting (remuneration, promotion, recognition and award) or intrinsic motives (satisfaction, learning by acting and so on), but also a genuine interest in people who are affected by a decision, considering their problems and needs. In this way, an ethical criterion is incorporated within the decision-making process. Another important aspect to consider is operative and evaluative learning of both the decision-maker and those with whom one is interacting.

Pérez-López suggested taking into consideration the learning of people and of the organisation. Thus, for instance, any business decision affecting two persons should consider questions such as: What results will I get? What will I learn in terms of both the operational and the evaluative? What will the other person learn in these two dimensions?
Two main drivers should guide the decision-making process. One is the external mission, which is centred on both the external results of a managerial decision, mainly profits and on the effects of such a decision on the distinctive competences of the organisation. The second is the internal mission, which regards the effect of a decision on the unity of the organisation, i.e. the identification of each and every one of those involved in the organisation with the aims of the organisation.

\section{Stakeholder management}

A fifth contribution is stakeholder management (Freeman, 2004; Freeman et al., 2010), which proposes that the manager's central task is to manage and integrate the relationships and interests of shareholders (groups who have a stake in the business), including shareholders, employees, customers, suppliers, communities, and other groups, in a way that ensures the long-term success of the firm. Focusing on satisfying the stakeholders' interests is not necessarily humanistic, but it could be a step in the direction of humanistic management, if the manager considers the legitimate interests of those who are affected by the activity of the firm and his or her responsibilities toward them.

Stakeholder management can be understood as a process to create value, not only for shareholders, but for all stakeholders. Argandoña (1998) interpreted Stakeholder Theory through the classic and humanistic concept of the common good. More recently, he also proposed a concept of value broader than the economic, as is the case in Stakeholder Theory (Argandoña, 2011). This concept of value is based, not on criteria external to the company, but on the core relationship between the company and its stakeholders. Drawing from Pérez-López's theory of human action (1991; 1993), Argandoña suggested that value is related to economic and intangible rewards, but also to psychological satisfaction, operative learning, quality of relationships, and personal flourishing. This makes stakeholder management more humanistic.

\section{Values-based management, business ethics, and} corporate social responsibility

A sixth humanistic contribution was the introduction of ethical values in managing organisations through what is called values-based management. In this approach, some values are introduced into the organisation through the mission statement and subsequently, into corporate plans and business plans.

Many companies now present a corporate values statement, although few are seriously committed to management by values. On the contrary, one can frequently observe attitudes that lack attention to moral judgments in making decisions. As Anderson points out, "Despite discussion in the popular and academic press, the connection between value judgments and economic success is still unclear in the minds of many 
executives" (1997:25) and businesses are managed with the supreme criterion of maximising the value for shareholders.

The humanistic approach, without forgetting a reasonable return for investors, emphasises managing, not only for economic value, but according to ethical and operative values. This contribution can be traced back to, at least, Barnard, mentioned above, who wrote that effective managers Inspire cooperative personal decisions by creating faith: Faith in common understanding, faith in the probability of success, faith in the ultimate satisfaction of personal motives, and faith in the integrity of objective authority, faith in the superiority of a common purpose as a personal aim of those who partake in it (1968:259).

Since then, others have insisted on the necessity of managing by values (Anderson, 1997; Blanchard and O'Connor, 1996; and McCoy, 1985, among others).

Leadership based on values or moral leadership has been also promoted in recent decades. Burns (1978), regarding transformational leadership, stressed that leaders have to inspire a sense of common purpose based on values. Several other authors have emphasised the importance of values for leadership or talk about ethical leadership. Greenleaf (1977) stressed the value of service for leadership, Ciulla (2004) talks about ethics as the heart of leadership and Sison (2003) pays special attention to the virtues of leaders and the moral capital that ethical habits confer, among many others.

Related to values are business ethics and corporate social responsibility, which tend to humanise organisations. Their importance is ever more widely-recognised, especially when some new scandal emerges. Many companies have institutionalised ethics through ethical codes, ethical offices, ethical training and so on. Large corporations, but also some small and medium-sized businesses, are involved in activities related to social responsibility.

\section{Personal competences}

A seventh contribution in favour of humanistic management is the increasing importance of personal competences, including moral character (Melé, 2012b, Ch. 6). This point is again in strong contrast to the Tayloristic view of management. In the latter, managers are basically technicians, that is to say, experts in organising work scientifically. The manager's moral character is completely irrelevant. This narrow view would probably be accepted by very few; however, there are other, more sophisticated approaches, in which the character of managers is also ignored. One is a certain 'scientificism' that rejects as a source of knowledge everything that cannot be measured. In this approach, the paramount importance of social sciences, especially economics, in management is emphasised. As a consequence, it is held that managers basically have to acquire technical skills and analytical competencies, whereas the managers' characters are seen as quite irrelevant.

The importance of personal virtues and putting people first have been highlighted by Collin (2001) in studying companies that have gone from good to great, and the character and style of their leaders. Good-to-great leaders possess a combination of personal humility and professional will. Although one might expect that these kinds of leaders started with vision and strategy, they actually attended to people first and strategy second.

\section{Positive organisational scholarship}

An eighth contribution to humanistic management is positive organisation scholarship, which has emerged in the last decade as an alternative approach to those that are conventional when studying organisations (Cameron et al., 2003; Cameron and Spreitzer, 2011). It focuses on positive processes, value transparency and extending the range of what constitutes a positive organisational outcome. This does not represent a single theory; rather, it is an umbrella covering different approaches focusing on dynamics that bring about what is considered positive or desirable. It examines positive phenomena within organisations, as well as positive organisational contexts. This approach expands the boundaries of these theories to make visible positive states, positive processes and positive relationships that are typically ignored in organisational studies. It tries to expose new and different mechanisms through which positive organisational dynamics and processes produce extraordinarily positive or unexpected outcomes. It pays attention to the role of virtues, organisations that foster virtuous behaviour and anything related to excellence, thriving, flourishing, abundance and resilience. Positive organisational scholarship does not stand in opposition to the array of self-help publications, but extends beyond them in its emphasis on rigorous, systematic and theory-based foundations for positive phenomena. This approach contributes to humanistic management by its purpose of seeking to understand what brings one closer to the best of the human condition.

\section{CONCLUSION}

From their origins, both business and management have been shaped excluding humanism and with a strong economistic view, in which human beings have been considered as mere instruments for gain. However, also from the very beginning, some voices have been heard demanding a better consideration for people, both for humanistic reasons and also through the argument that a humanistic approach can contribute to better performance.

We have discussed a number of relatively recent managerial approaches that show a certain contribution to or movement towards more humanistic positions. We are advancing from rigid job designs and organisational 
structures to person-organisation-fit structures, although certainly some sweat shops still persist in too many places; from organisations in which each person is just a cog in the business machine to organisations in which people are put first, with a greater degree of involvement, commitment, and participation; from seeing firms as a set of contracts to considering the business firm as a community of people; from a management aligned to maximisation of shareholder value to management by values and giving importance to ethical leadership; from approaches exclusively focused on the structure to a vision in which personal competences are fully recognised. In addition, positive organisational scholarship opened the door to humanistic practices that lead to positive outcomes in organisations, and Stakeholder Theory, quite widespread now-a-days, could be interpreted through the humanistic lens. In our opinion, another promising proposal that may be worth developing is Pérez-López's comprehensive approach. In spite of these valuable contributions, humanistic management is still 'under construction,' and renewed efforts will be necessary for it to become a worthy alternative to management theories based on the economic paradigm.

Further development of humanistic management may require a view of human beings that considers both their individual and relational-social condition and other essential anthropological features. As noted, many management approaches are based on a radical individualism, but there are other possible ways of understanding business and management inspired by other cultural traditions. Thus, according to Thomas et al. (2013), some European business schools stress elements of the European cultural tradition. Locke and Spender (2011) mentioned that Christianity, Islam, and Confucianism relate to business in different ways than does radical individualism. This is also true for Hinduism (Alexander and Buckingham, 2011) and for the African wisdom of Ubuntu (Lutz, 2009; Mbigi and Maree, 2005; Sulamoyo, 2010). Hopefully, these will inspire future developments of humanistic management.

\section{REFERENCES}

Acevedo, A. (2012). Personalist business ethics and humanistic management: Insights from Jacques Maritain. Journal of Business Ethics, 105, 197-219.

Adler, P. S. (2004). 'Corporate scandals: It's time for reflection in business schools. Academy of Management Executive, 16, 148-9.

Aktour, O. (1992). Management and theories of organizations in the 1990s: Toward a critical radical humanism. Academy of Management Review, 17, 407-31.

Alexander, J. M. and Buckingham, J. (2011). Common good leadership in business management: An ethical model from the Indian tradition. Business Ethics: A European Review, 20, 317-27.

Amann, W., Pirson, M., Dierksmeier, C., Kimakowitz, E. V., and Spitzeck, H. (Eds.). (2011). Business schools under fire: Humanistic management education as the way forward. New York: Palgrave-MacMillan. Anderson, C. (1997). Values-based management. Academy of Management Executive, 11, 25-46.
Andreu, R, and Rosanas, J. M. (2012). Manifiesto for a better management. A rational and humanist view. In J. M. Rosanas, and J. E. Ricart, (Eds.). Towards a new theory of the firm. Humanizing the firm and the management profession. (pp. 109-50). Madrid: Fundación BBVA.

Argandoña, A. (1998). The stakeholder theory and the common good. Journal of Business Ethics, 17, 1093-102.

Argandoña, A. (2008) Integrating ethics into action theory and organizational theory. Journal of Business Ethics, 78, 435-46.

Argandoña, A. (2011). Stakeholder theory and value creation. IESE Business School Working Paper No. 922.

Argyris, C. (1957). Personality and organization. The conflict between system and individual. New York: Harper.

Barnard, C. (1968; 1938). The functions of the executive. London: Oxford University Press.

Beaudreau, B. C. (2012). A humanistic theory of economic behavior. Journal of Socio-Economics, 41, 222-34.

Benedict XVI. (2009). Encyclical letter: Caritas in veritate. [Online]. Available from: http://www.vatican.va/holy_father/benedict_xvi/encyclicals/ documents/hf_ben-xvi_enc_20090629_caritas-in-veritate_en.html. [Last accessed on 2013 Sep 30].

Bennis, W. G., and O'Toole, J. (2005). How business schools lost their way. Harvard Business Review, 83, 96-104.

Blanchard, K., and O'Connor, M. (1996). Managing by values. San Francisco: Berrett-Koehler.

Burns, J. G. (1978). Leadership. New York: Harper and Row.

Cable, D. M., and Judge, T. A. (1994). Pay preferences and job search decisions: A person-organization perspective. Personnel Psychology, 47, 317-48.

Cameron, K. S., Dutton, J. E., and Quinn, R. (2003). Positive organizational scholarship. San Francisco: Berrett-Koehler.

Cameron, K. S., and Spreitzer, G. M. (Eds.). (2011). Oxford handbook of positive organizational scholarship. Oxford: Oxford University Press.

Chatman, J. A. (1989). Improving interactional organizational research: A model of person-organization fit. Academy of Management Review, $14,333-49$.

Ciulla, J. (1998). Ethics, the heart of leadership. London: Quorum Books. Collins, J. (2001). Good to great: Why some companies make the leap, and others don't. London: Random House.

Cohen, D. and L. Prusak (2001), In Good Company: How Social Capital Makes Organizations Work. Campbridge, MA: Harvard Business School Press.

Collins, J., and Porras, J. I. (1994). Built to last: Successful habits of visionary companies. New York: Harper Collins.

Cunningham, M. E., and Tichy, N. (1983). Planning for humanism. Journal of Business Strategy, 3, 87-90.

Daley, D. M. (1986). Humanistic management and organizational success: The effect of job and work environment characteristics on organizational effectiveness, public responsiveness, and job satisfaction. Public Personnel Management, 15, 131-42.

Drucker, P. F. (1973). Managers: Tasks, responsibilities, practices. New York: Harper and Row.

Follett, M. P. (1940). Dynamic administration. The collected papers of Mary Parker Follett. In H. C. Metcalf, and L. Urwick (Eds). New York, London: Harper and Brothers.

Follett, M. P. (1987). La primera edición es de 1949 (Management Publication Data, London). Freedom and co-ordination. Lectures in business organization. In L. Urwick (Ed), Edited, with an introduction. New York, London: Longmans, Green and Co.

Freeman, R. E. (2004). A stakeholder theory of the modern corporation. In T.L. Beauchamp, and N. E. Bowie, (Eds.). Ethical Theory and Business. Upper Saddle River, NJ: Pearson-Prentice Hall; 55-64.

Freeman, R. E., Harrison, J. S., Wicks, A. C., Parmar, B. L., and de Colle, S. (2010). Stakeholder theory: The state of the art. New York: Cambridge University Press.

French, W. L., and Bell, C. H. (1999). Organizational development: Behavioral science intervention for organization improvement. Englewoods Cliffs, NJ: Prentice Hall.

Friedman, M. (1970). The social responsibility of business is to increase 
its profits. New York Times Magazine, 32-3, 122, 126.

Friedman, M., and Friedman, R. (1962). Capitalism and freedom. Chicago: University of Chicago Press.

Ghoshal, S. (2005). Bad management theories are destroying good management practices. Academy of Management Learning and Education, 4, 75-91.

Ghoshal, S., Bartlett, C. A., and Moran, P. (1999). A new manifesto for management. Sloan Management Review, 40, 9-20.

Gordon, R., and Howell, J. (1959). Higher education for business. New York: Columbia University Press.

Graham, P. (Ed). (1995). Mary Parker Follett - Prophet of management: A celebration of writings from the 1920s. Introduction by Peter Drucker. Boston, Massachusetts, USA: Harvard Business School Press.

Greenleaf, R. K. (1977). Servant leadership. A journey into the nature of legitimate power and greatness. Mahwah, New York: Paulist Press.

Handy, C. (1999). The new language of business. Director, 52, 50-3.

Hansen, M. T. (1999). The search-transfer problem: The role of weak ties in sharing knowledge across organization subunits. Administrative Science Quarterly, 44, 82.

Herzberg, F. (1959). The motivation to work. New York: Wiley and Sons. Herzberg, F. (1968). One more time: How do you motivate employees? Harvard Business Review, 46, 53-62.

Herzberg, F. (1976). The managerial choice: To be efficient and to be human. Homewood, IL: Dow Jones-Irwin.

Jensen, M. C. (2001). Value maximization, stakeholder theory, and the corporate objective function. European Financial Management, 7 (3), 297-317.

Jensen, M. C., and Meckling, W. H. (1976). Theory of the firm: Managerial behavior, agency cost, and ownership structure. Journal of Financial Economics, 3, 305-60.

Judge, T. A., and Bretz, R. D., Jr. (1992). Effects of work values on job choice decisions. Journal of Applied Psychology, 77, 261-71.

Kimakowitz, E. V., Pirson, M., Spitzeck, H., Dierksmeier, C., and Amann, W. (Eds.). (2011). Humanistic management in practice. New York: Palgrave-MacMillan.

Kogut, B., and Zander, U. (1995). Knowledge, market failure and the multinational enterprise: A reply. Journal of International Business Studies, 26, 417-26.

Kristof, A. L. (1996). Person-organization fit: An integrative review of its conceptualizations, measurement, and implications. Personnel Psychology, 49, 1-49.

Kurzynski, M. (2009). Peter Drucker: Modern day Aristotle for the business community. Journal of Management History, 15, 357-74.

Lilienthal, D. E. (1967). Management: A humanistic art. New York: Colombia University Press.

Lilienthal, D. E. (1968). The goal of management is to "get things done." Columbia Journal of World Business, 3, 55-9.

Locke, R., and Spender, J. C. (2011). Confronting managerialism: How the business elite and their schools threw our lives out of balance. London: ZED Books.

Lutz, D. (2009). African ubuntu philosophy and global management. Journal of Business Ethics, 84, Suppl 3, 313-28.

Maak, T., and Pless, N. (2009). Business leaders as citizens of the world. Advancing humanism on a global scale. Journal of Business Ethics, 88, 537-50.

Maritain, J. (1996). Integral humanism, freedom in the modern world, and a letter on independence. In O. Bird (Ed.). (Original: Integral humanism: Temporal and spiritual problems of a new Christendom, 1938). The collected works of Jacques Maritain. Notre Dame, IN: University of Notre Dame Press. Marqués, A. (2005). Para una crítica filosófica del economicismo moderno. Revista de Fomento Social, 239, 407-33.

Maslow, A. H. (1954). Motivation and personality. New York: Harper and Brothers.

Mayo, E. (1933). The human problems of an industrial civilization. New York: Macmillan.

Mayo, E. (1946). The social problems of an industrial civilization.
Cambridge: Cambridge University Press.

Mbigi, L., and Maree, J. (2005). Ubuntu: The spirit of African transformation management Randburg, South Africa: Knowres.

McCoy, C. (1985). Management by values: The ethical difference on corporate policy and performance. Marchfield, MA: Pitman.

McGregor, D. V. (1960). The human side of enterprise. New York: McGraw-Hill.

Melé, D. (2003). The challenge of humanistic management. Journal of Business Ethics, 44, 77-88.

Melé, D. (2009). Editorial introduction: Towards a more humanistic management. Journal of Business Ethics, 88, 413-6.

Melé, D. (2012a). The firm as a "community of persons": A pillar of humanistic business ethos. Journal of Business Ethics, 106 (1), 89-101.

Melé, D. (2012b). Management ethics: Placing ethics at the core of good management New York: Palgrave MacMillan.

Melé, D., and Dierksmeier, C. (Eds.). (2012). Human development in business. Values and humanistic management in the Encyclical "Caritas in Veritate». New York: Palgrave-MacMillan.

Mintzberg, H. (2004). Managers not MBAs. San Francisco: Berrett-Koehler. Mitroff, I. I. (2004). An open letter to the deans and the faculties of American business schools. Journal of Business Ethics, 54, 185-9.

Moore, G. (2005). Humanizing business: A modern virtue ethics approach. Business Ethics Quarterly, 15, 237-55.

Moran, P. (2001), Structural vs. Relational Embeddedness: Social Capital and Managerial Performance. Strategic Management Journal, 26, 1129-51. Nahapiet, J. and S. Ghoshal (1998) 'Social capital, Intellectual Capital, and the Organizational Advantage. Academy of Management Review, 23, 242-66.

Pérez López, J. A. (1991). Teoría de la acción humana en las organizaciones. La acción personal. Madrid: Rialp.

Pérez-López, J. A. (1993). Fundamentos de la dirección de empresas. Madrid: Rialp.

Peters, T. J., and Waterman, R. H. (1982). In search of excellence: Lessons from America's best run companies. London: Harper and Row.

Preece, G. R. (Ed.). (2002). Rethinking Peter Singer: A Christian critique. Downser Grove, IL: InterVarsity Press.

Rosanas, J. (2008). Beyond economic criteria: A humanistic approach to organizational survival. Journal of Business Ethics, 78 (3), 447-62.

Rosanas, J. M. (2006). Qué cosas diferentes dijo Juan Antonio Pérez López?' Revista de Antiguos Alumnos del IESE, September, 38-42.

Rosanas, J. M., and Ricart, J. E. (Eds.). (2012). Towards a new theory of the firm. Humanizing the firm and the management profession. Madrid: Fundación BBVA.

Schwartz, M. (2004). Drucker's communitarian vision and its implications for business ethics. Business Ethics: A European Review, 13 (4), 288-301. Sison, A. J. (2003). The moral capital of leaders. Why virtue matters. Cheltenham, UK, Northampton; MA, USA: Edward Elgar.

Sisón, A. J., Hartman, E. M., and Fontrodona, J. (Guest Eds.). (2012). Introduction reviving tradition: Virtue and the common good in business and management. Business Ethics Quarterly, 31, 207-10.

Solomon, C. R. (1992). Ethics and excellence: Cooperation and integrity in business. New York: Oxford University Press.

Solomon, C. R. (1994). The new word of business. Ethics and free enterprise in the global 1990s. Lanham, Maryland, USA: Roman and Littjefield Publishers.

Spitzeck, H. (2011). An integrated model of humanistic management. Journal of Business Ethics, 99, 51-62.

Spitzeck, H., Amann, W., Pirson, M., Khan, S., and Kimakowitz, E. V (Eds.) (2009). Humanism in business - State of the art. A reflection on humanistic values in today's business world. Cambridge: Cambridge University Press. Sulamoyo, D. (2010). "I am because we are": Ubuntu as a cultural strategy for OD and change in sub-Saharan Africa. Organization Development Journal, 28 (4), 41-51.

Swart, J. C. (1973). The worth of humanistic management: Some contemporary examples. Business Horizons, 16, 41-50.

Taylor, F. W. (1911). The principles of scientific management. New York: Harper. 
Thomas, H., Thomas, L., and Wilson, A. (2013). Promises fulfilled and unfulfilled in management education. Bingley: Emerald Publishing.

Uzzi, B. (1996). The sources and consequences of embeddedness for the economic performance of organizations: The network effects. American Sociological Review, 61 (4), 674-98.

Williamson, O. E. (1975). Markets and hierarchies: Analysis and antitrust implications: A study in the economics of internal organization. New York: Free Press.
Wolf, W. B. (1974). The basic Barnard: An introduction to Chester I. Barnard and his theories of organization and management Ithaca, New York: New York State School of Industrial and Labor Relations - Cornell University.

How to cite this article: Melé D. Antecedents and current situation of humanistic management. Afr J Bus Ethics 2013;7:10-9.

Source of Support: Nil, Conflict of Interest: None declared

\section{AUTHOR}

Domènec Melé (PhD in Industrial Engineering and $\mathrm{PhD}$ in Theology) is professor and holder of the Chair of Business Ethics at IESE Business School, University of Navarra, Spain. Over the last 25 years, he has researched and written extensively on the areas of business ethics, business in society and Catholic Social Thought. He authored, co-authored or edited 12 books, including Business Ethics in Action (Palgrave, 2009), Management Ethics (Palgrave, 2012) and Human Development in Business. Values and Humanistic Management in the in the Encyclical "Caritas in Veritate» (Palgrave, 2012). In addition, he has published over 50 scientific chapters and articles in referred journals and some 20 case studies. Prof. Melé serves as section editor of Journal of Business Ethics and in several editorial boards of referred journal and has been guest or co-guest editor of seven special issues of scientific journals. 
Reproduced with permission of the copyright owner. Further reproduction prohibited without permission. 